\title{
COVID-19 vaccines and decreased transmission of SARS-CoV-2
}

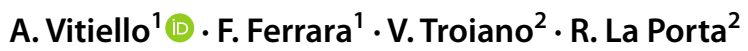

Received: 2 July 2021 / Accepted: 8 July 2021 / Published online: 19 July 2021

(c) The Author(s), under exclusive licence to Springer Nature Switzerland AG 2021

\begin{abstract}
A massive COVID-19 vaccination campaign is underway worldwide. Epidemiological data from studies indicate excellent efficacy and safety profile for COVID-19 vaccines. However, there are few data from studies on the effect of decreasing the probability of infection of vaccinated subjects compared to unvaccinated subjects. In this short communication, we describe some evidence on this important and current topic providing useful personal reflections.
\end{abstract}

Keywords Vaccines $\cdot$ COVID-19 $\cdot$ SARS-CoV-2 $\cdot$ Pandemic

\section{Vaccines and virus transmission}

The global COVID-19 pandemic is currently underway (Khan et al. 2020). Pharmacological treatments for the treatment of COVID-19 infection are mostly directed at avoiding severe complications of the disease (Vitiello and Ferrara 2021a, 2021b, 2021c; Ferrara and Vitiello 2021a). To date, there are no antivirals directed against SARSCoV-2, good efficacy has been demonstrated for some antivirals, authorized for other infectious diseases, such as Remdesivir(Vitiello et al. 1971; Vitiello and Ferrara 2020; Ferrara et al. 2020; Ferrara and Vitiello 2021b). Since December 2020, a massive vaccination campaign has begun worldwide. The vaccines in use, using different methods, mRNA, viral vector, to date the clinical evidence in the epidemiological data post-authorization show excellent efficacy and safety profile (Vitiello et al. 2021a; Polack et al. 2020; Knoll and Wonodi 2021). However, probably what has been poorly studied in the phase 3 pre-registration studies and in

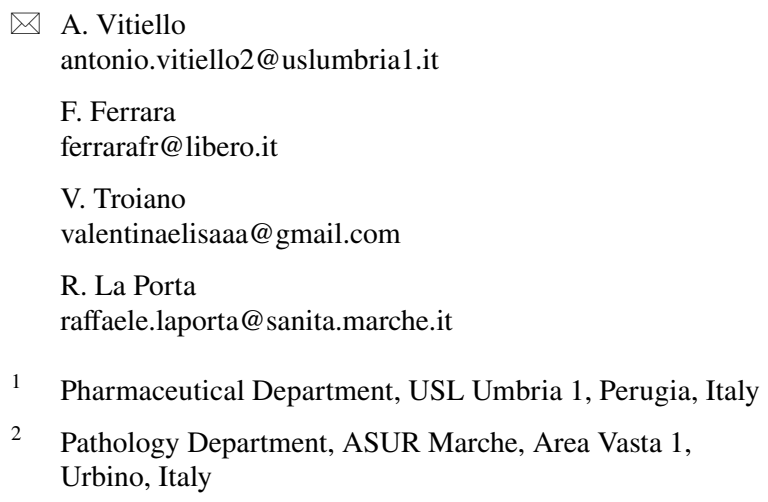

the post-authorization clinical trials, is whether the vaccinated subject infects with the same frequency and probability as an unvaccinated subject, and, if the vaccinated subject can be equally contagious as an unvaccinated and COVID19-positive subject. Pre-registration phase 3 clinical trials, as is traditional for vaccines, evaluate therapeutic efficacy by investigating the vaccinated subject's protection from the disease. Even for COVID-19 vaccines, preregistrative phase 3 studies have evaluated the protection of subjects from disease, albeit with different results among vaccines (Lurie et al. 2020; Voysey et al. 2021). However, it is certain that protection from severe disease by vaccines is of enormous importance, but probably of equal importance is understanding whether vaccination also decreases virus transmission and the number of people infected (Wiersinga et al. 2020). These goals are made even more important given the current lack of antiviral drugs directed against SARS-CoV-2 (Vitiello et al. 2021b, 2021c).

\section{Different COVID-19 vaccines and delta variant}

Several vaccines against COVID-19 are currently licensed, using different modes of action. Epidemiological data also show different efficacy, which may also indirectly influence the ability to decrease virus transmission. The BioNTech/ Pfizer BNT162b2 mRNA method vaccine conferred 95\% protection against COVID-19 in persons 16 years of age or older (Polack et al. 2020). The Astrazeneca viral vector vaccine has demonstrated $70.4 \%$ efficacy in preventing 
severe COVID-19 (Knoll and Wonodi 2021). The J\&J/Janssen COVID-19 Vaccine was $66.3 \%$ effective in preventing COVID-19 infection in people who received the vaccine and had no evidence of being previously infected (Sadoff et al. 2021). Recently, a new SARS-CoV-2 variant, named Delta variant, has been identified and is responsible for a strong wave of epidemic with high incidence of deaths and infected in India. Delta variant appears to be about $60 \%$ more transmissible than the already highly infectious Alpha variant (also called B.1.1.7). Delta is moderately resistant to vaccines, particularly in people who have received a single dose. One study shows that a single dose of vaccine from AstraZeneca or Pfizer reduced a person's risk of developing COVID-19 symptoms caused by the Delta variant by $33 \%$, compared with $50 \%$ for the Alpha variant. A second dose of the AstraZeneca vaccine increased protection against Delta to $60 \%$ (compared with $66 \%$ against Alpha), while two doses of the Pfizer vaccine were $88 \%$ effective (compared with 93\% effective against Alpha).

\section{Clinical evidence and decreased transmission of SARS-CoV-2}

Recent evidence shows a decrease in contagiousness among vaccinated people. In a study carried out in Israel, the viral load present in the nasal mucosa of a sample of healthcare workers was evaluated on a weekly basis. The conclusion of the study showed that in vaccinated and COVID-19-positive persons, the viral load was 2-4 times lower than in unvaccinated persons (Callaway 2021). Another study, evaluating the amount of viral RNA present in approximately 16,000 nasal swabs showed that the viral load of SARS-CoV-2 in COVID-19-positive and vaccinated subjects is 1.6-20 times lower than the viral load present in infected and unvaccinated subjects (Levine-Tiefenbrun et al. 2021). Another study performed in the United States was conducted on a sample of 3950 health care workers examined between December 14, 2020 and March 13, 2021. The results showed that vaccines had an efficacy in preventing infection of $90 \%$ 14 days after the second dose and $80 \% 14$ days after the first dose (Krause et al. 2021).

\section{Discussions}

The scientific interpretation of the results of these clinical studies clearly demonstrates the correlation between the decrease in SARS-CoV-2 viral load and probability of infection, and vaccinated subjects. The molecular hypothesis underlying these results, suggest that in the vaccinated subject and COVID-19 positive may be present the virus, structurally intact, but immediately covered with antibodies of the subject, which make the virus unable to infect other people. Probably this may also be related to the fact that asymptomatic COVID19-positive individuals are less contagious than individuals with severe infection, precisely because in asymptomatic individuals the immune system has an excellent response, immediately attacking the virus, slowing its replication and decreasing its potency and the likelihood of infecting other people (Petter et al. 2021; Thompson et al. 2021; Wang et al. 2020; Yu and Yang 2020; Huff and Singh 2020). This hypothesis is further reinforced by the evidence showing that people with lower viral load in circulation transmit are less contagious, further suggesting that asymptomatic infections are less likely to infect other individuals. However, it would be essential to be able to vaccinate the largest number of the world's population in a short time, avoiding huge differences between the countries.

\section{Conclusions}

Current clinical evidence shows that COVID-19 vaccination protects against severe symptoms of the disease but is also an important tool to decrease the spread of the virus and the rate of infection. At this point in time, the global COVID-19 pandemic is complex, some countries have vaccinated a large portion of their population, others have difficulty accessing vaccination, and there is a wide variety of measures put in place and closures between the countries. These discrepancies may bring out variants of the virus, and prolong the global pandemic phase. Vaccinated individuals are likely to be less likely to transmit the virus; however, it remains critical to continue to maintain responsible behaviors.

Author contributions All the authors contributed equally to the manuscript and had the opportunity to revise and approve the final text.

Funding None.

Data availability No availability of supporting data.

\section{Declarations}

Conflict of interest None of the authors has conflicts of interest.

Ethical approval Not applicable.

Consent to participate Not applicable.

\section{References}

Callaway E (2021) Delta coronavirus variant: scientists brace for impact. Nature 595(7865):17-18. https://doi.org/10.1038/d41586021-01696-3 (PMID: 34158664)

Ferrara F, Vitiello A (2021a) Scientific hypothesis for treatment of COVID-19's lung lesions by adjusting ACE/ACE2 imbalance. 
Cardiovasc Toxicol. https://doi.org/10.1007/s12012-02109649-y (Epub ahead of print. PMID: 33835386; PMCID: PMC8032553)

Ferrara F, Vitiello A (2021b) Efficacy of synthetic glucocorticoids in COVID-19 endothelites. Naunyn Schmiedeberg's Arch Pharmacol. https://doi.org/10.1007/s00210-021-02049-7

Ferrara F, Porta R, D'Aiuto V, Vitiello A (2020) Remdesivir and COVID-19. Ir J Med Sci. https://doi.org/10.1007/ s11845-020-02401-5

Huff HV, Singh A (2020) Asymptomatic transmission during the coronavirus disease 2019 pandemic and implications for public health strategies. Clin Infect Dis 71(10):2752-2756. https:// doi.org/10.1093/cid/ciaa654 (PMID: 32463076; PMCID: PMC7314132)

Khan M, Adil SF, Alkhathlan HZ, Tahir MN, Saif S, Khan M, Khan ST (2020) COVID-19: a global challenge with old history, epidemiology and progress so far. Molecules 26(1):39. https://doi. org/10.3390/molecules26010039 (PMID: 33374759; PMCID: PMC7795815)

Knoll MD, Wonodi C (2021) Oxford-AstraZeneca COVID-19 vaccine efficacy. Lancet 397(10269):72-74. https://doi.org/10. 1016/S0140-6736(20)32623-4 (Epub 2020 Dec 8. PMID: 33306990; PMCID: PMC7832220)

Krause PR, Fleming TR, Longini IM, Peto R, Briand S, Heymann DL, Beral V, Snape MD, Rees H, Ropero AM, Balicer RD, Cramer JP, Muñoz-Fontela C, Gruber M, Gaspar R, Singh JA, Subbarao K, Van Kerkhove MD, Swaminathan S, Ryan MJ, Henao-Restrepo AM (2021) SARS-CoV-2 variants and vaccines. N Engl J Med. https://doi.org/10.1056/NEJMsr2105280

Levine-Tiefenbrun M, Yelin I, Katz R, Herzel E, Golan Z, Schreiber L, Wolf T, Nadler V, Ben-Tov A, Kuint J, Gazit S, Patalon T, Chodick G, Kishony R (2021) Initial report of decreased SARS$\mathrm{CoV}-2$ viral load after inoculation with the BNT162b2 vaccine. Nat Med 27(5):790-792. https://doi.org/10.1038/s41591-02101316-7 (Epub 2021 Mar 29. PMID: 33782619)

Lurie N, Saville M, Hatchett R, Halton J (2020) Developing Covid19 vaccines at pandemic speed. N Engl J Med 382(21):19691973. https://doi.org/10.1056/NEJMp2005630 (Epub 2020 Mar 30 PMID: 32227757)

Petter E, Mor O, Zuckerman N, Oz-Levi D, Younger A, Aran D, Erlich Y (2021) Initial real world evidence for lower viral load of individuals who have been vaccinated by BNT162b2. medRxiv. https://doi.org/10.1101/2021.02.08.21251329

Polack FP, Thomas SJ, Kitchin N, Absalon J, Gurtman A, Lockhart S, Perez JL, Pérez Marc G, Moreira ED, Zerbini C, Bailey R, Swanson KA, Roychoudhury S, Koury K, Li P, Kalina WV, Cooper D, Frenck RW Jr, Hammitt LL, Türeci Ö, Nell H, Schaefer A, Ünal S, Tresnan DB, Mather S, Dormitzer PR, Sahin U, Jansen KU, Gruber WC, C4591001 Clinical Trial Group (2020) Safety and efficacy of the BNT162b2 mRNA covid-19 vaccine. N Engl J Med 383(27):2603-2615. https:// doi.org/10.1056/NEJMoa2034577 (Epub 2020 Dec 10. PMID: 33301246; PMCID: PMC7745181)

Sadoff J, Le Gars M, Shukarev G, Heerwegh D, Truyers C, de Groot AM, Stoop J, Tete S, Van Damme W, Leroux-Roels I, Berghmans PJ, Kimmel M, Van Damme P, de Hoon J, Smith W, Stephenson KE, De Rosa SC, Cohen KW, McElrath MJ, Cormier E, Scheper G, Barouch DH, Hendriks J, Struyf F, Douoguih M, Van Hoof J, Schuitemaker H (2021) Interim results of a phase 1-2a trial of Ad26.COV2.S Covid-19 vaccine. N Engl J Med 384(19):1824-1835. https://doi.org/10.1056/NEJMoa2034201

Thompson MG, Burgess JL, Naleway AL, Tyner HL, Yoon SK, Meece J, Olsho LEW, Caban-Martinez AJ, Fowlkes A, Lutrick K, Kuntz JL, Dunnigan K, Odean MJ, Hegmann KT, Stefanski E, Edwards LJ, Schaefer-Solle N, Grant L, Ellingson K, Groom HC, Zunie T, Thiese MS, Ivacic L, Wesley MG, Lamberte JM,
Sun X, Smith ME, Phillips AL, Groover KD, Yoo YM, Gerald J, Brown RT, Herring MK, Joseph G, Beitel S, Morrill TC, Mak J, Rivers P, Harris KM, Hunt DR, Arvay ML, Kutty P, Fry AM, Gaglani M (2021) Interim estimates of vaccine effectiveness of BNT162b2 and mRNA-1273 COVID-19 vaccines in preventing SARS-CoV-2 infection among health care personnel, first responders, and other essential and frontline workers-eight U.S. locations December 2020-March 2021. MMWR Morb Mortal Wkly Rep 70(13):495-500. https://doi.org/10.15585/ mmwr.mm7013e3 (PMID: 33793460; PMCID: PMC8022879)

Vitiello A, Ferrara F (2020) Remdesivir versus ritonavir/lopinavir in COVID-19 patients. Ir J Med Sci. https://doi.org/10.1007/ s11845-020-02440-y

Vitiello A, Ferrara F (2021a) Anti-fibrotic therapy for the treatment of pulmonary sequelae in patients healed by COVID-19. Lung India 38(Supplement):S129-S130. https://doi.org/10.4103/lungi ndia.lungindia_803_20 (PMID: 33687000)

Vitiello A, Ferrara F (2021b) Pharmacological agents modifying the renin angiotensin and natriuretic peptide systems in COVID19 patients. Wien Klin Wochenschr. https://doi.org/10.1007/ s00508-021-01855-6 (Epub ahead of print. PMID: 33877436)

Vitiello A, Ferrara F (2021c) Colchicine and SARS-CoV-2: management of the hyperinflammatory state. Respir Med. https://doi. org/10.1016/j.rmed.2021.106322

Vitiello A, Ferrara F, La Porta R (1971) Remdesivir and COVID-19 infection, therapeutic benefits or unnecessary risks? Ir J Med Sci. https://doi.org/10.1007/s11845-020-02482-2

Vitiello A, Porta R, Pianesi L, Ferrara F (2021a) COVID-19 pandemic: vaccine and new monoclonal antibodies, point of view. Ir J Med Sci. https://doi.org/10.1007/s11845-021-02584-5 (Epub ahead of print. PMID: 33710481)

Vitiello A, La Porta R, D'Aiuto V, Ferrara F (2021b) Pharmacological approach for the reduction of inflammatory and prothrombotic hyperactive state in COVID-19 positive patients by acting on complement cascade. Hum Immunol. https://doi.org/ 10.1016/j.humimm.2021.01.007

Vitiello A, Pelliccia C, Ferrara F (2021c) Drugs acting on the reninangiotensin system and SARS-CoV-2. Drug Discov Today. https://doi.org/10.1016/j.drudis.2021.01.010

Voysey M, Clemens SAC, Madhi SA, Weckx LY, Folegatti PM, Aley PK, Angus B, Baillie VL, Barnabas SL, Bhorat QE, Bibi S, Briner C, Cicconi P, Collins AM, Colin-Jones R, Cutland CL, Darton TC, Dheda K, Duncan CJA, Emary KRW, Ewer KJ, Fairlie L, Faust SN, Feng S, Ferreira DM, Finn A, Goodman AL, Green CM, Green CA, Heath PT, Hill C, Hill H, Hirsch I, Hodgson SHC, Izu A, Jackson S, Jenkin D, Joe CCD, Kerridge S, Koen A, Kwatra G, Lazarus R, Lawrie AM, Lelliott A, Libri V, Lillie PJ, Mallory R, Mendes AVA, Milan EP, Minassian AM, McGregor A, Morrison H, Mujadidi YF, Nana A, O'Reilly PJ, Padayachee SD, Pittella A, Plested E, Pollock KM, Ramasamy MN, Rhead S, Schwarzbold AV, Singh N, Smith A, Song R, Snape MD, Sprinz E, Sutherland RK, Tarrant R, Thomson EC, Török ME, Toshner M, Turner DPJ, Vekemans J, Villafana TL, Watson MEE, Williams CJ, Douglas AD, Hill AVS, Lambe T, Gilbert SC, Pollard AJ, Oxford COVID Vaccine Trial Group (2021) Safety and efficacy of the ChAdOx $1 \mathrm{nCoV}-19$ vaccine (AZD1222) against SARS-CoV-2: an interim analysis of four randomised controlled trials in Brazil, South Africa, and the UK. Lancet 397(10269):99-111. https://doi.org/10.1016/S01406736(20)32661-1 (PMID: 33306989; PMCID: PMC7723445)

Wang R, Chen J, Hozumi Y, Yin C, Wei GW (2020) Decoding asymptomatic COVID-19 infection and transmission. J Phys Chem Lett 11(23):10007-10015. https://doi.org/10.1021/acs. jpclett.0c02765 (PMID: 33179934; PMCID: PMC8150094)

Wiersinga WJ, Rhodes A, Cheng AC, Peacock SJ, Prescott HC (2020) Pathophysiology, transmission, diagnosis, and treatment 
of coronavirus disease 2019 (COVID-19): a review. JAMA 324(8):782-793. https://doi.org/10.1001/jama.2020.12839 (PMID: 32648899)

Yu X, Yang R (2020) COVID19 transmission through asymptomatic carriers is a challenge to containment. Influenza Other Respir Viruses 14(4):474-475. https://doi.org/10.1111/irv.12743 (Epub 2020 Apr 15. PMID: 32246886; PMCID: PMC7228388)
Publisher's Note Springer Nature remains neutral with regard to jurisdictional claims in published maps and institutional affiliations. 